\title{
ARTÍCULOS
}

\section{ESCÁNDALOS DE CORRUPCIÓN E INVESTIGACIÓN GUBERNAMENTAL. REFLEXIONES EN TORNO AL CASO DE SANTA FE (ARGENTINA), 1890-1894.}

\author{
Romina Garcilazo \\ Universidad Nacional de Rosario \\ rominagarhistoria@gmail.com
}

\begin{abstract}
Resumen: El presente artículo tiene como objetivo analizar ciertos tópicos que recorren la llamada "Nueva" Historia Cultural de la Corrupción Política como aquellos que pivotean en torno a los términos vinculados al concepto de corrupción, las percepciones que los protagonistas esgrimen respecto a los hechos escandalosos, la derivación de las denuncias en investigaciones gubernamentales y presentaciones judiciales y la actuación de la prensa en el proceso investigativo. Para ello, nos centraremos en la pesquisa emprendida por el comisionado gubernamental Ricardo Pillado en el Banco Provincial de Santa Fe (Argentina) referida a las anomalías registradas en la entidad durante los años anteriores a la crisis de 1890. El caso resulta significativo porque, por primera vez, las denuncias de corrupción sobre lo sucedido en la institución bancaria no provenían de la esfera periodística, sino que eran originadas desde el ámbito estatal.
\end{abstract}

Palabras clave: Corrupción, escándalos, Santa Fe, siglo XIX, Banco Provincial de Santa Fe, investigación gubernamental, Ricardo Pillado.

Tittle: CORRUPTION SCANDALS AND GOVERNMENT INVESTIGATION. REFLECTIONS ON THE CASE OF SANTA FE (ARGENTINA), 1890-1894.

\begin{abstract}
This article aims to analyze certain topics that run through the so-called "New" Cultural History of Political Corruption, such as those that revolve around the terms related to the concept of corruption, the perceptions that the protagonists hold regard to the scandalous events the derivation of denunciation in government investigations and judicial presentations and the role played by the press in the investigative process. To this end, we will focus on the research undertaken by the government commissioner, Ricardo Pillado, in the Provincial Bank of Santa Fe (Argentina) referring to the anomalies registered in the entity during the years preceding the crisis of 1890 . The case is significant because, for the first time, the denunciation of corruption in the banking institution did not come from the journalistic sphere but originated from the state level.
\end{abstract}

Keywords: Corruption, scandals, Santa Fe, $19^{\text {th }}$ century, Banco Provincial de Santa Fe, Santa Fe, government investigation, Ricardo Pillado.

Recibido: 06-06-2021

Aceptado: 01-07-2021

Cómo citar este artículo: GARCILAZO, Romina. Escándalos de corrupción e investigación gubernamental. Reflexiones en torno al caso de Santa Fe (Argentina), 1890-1894. Naveg@mérica. Revista electrónica editada por la Asociación Española de Americanistas [en línea]. 2021, n. 27. Disponible en: <http://revistas.um.es/navegamerica>. [Consulta: Fecha de consulta]. ISSN 1989-211X. 


\section{Introducción}

“[...] Importantísimo para el comercio, para la Provincia y para el crédito del país, es la misión delicada que trae el señor Ricardo Pillado.

De su resultado se esperan grandes descubrimientos y revelaciones [...]"1.

Con estas palabras de júbilo el diario La Capital de la ciudad santafesina de Rosario - en agosto de 1890 - informaba la llegada del enviado del gobierno, Ricardo Pillado. El Ministro de Hacienda de la Nación del presidente Carlos Pellegrini (1890-1892), Vicente F. López, le había encomendado la difícil tarea de inspeccionar el estado económico del Banco Provincial de Santa Fe (en adelante, BPSF). Esta entidad del crédito, una de las más dinámicas de la región, había sido cuestionada -al igual que otras casas bancarias del país - por las irregularidades evidenciadas durante las gestiones del presidente Miguel Juárez Celman (1886-1890) y del gobernador José Gálvez (1886-1890). Ambos líderes pertenecieron al Partido Autonomista Nacional (PAN). Este espacio político, al igual que otros partidos decimonónicos, se caracterizó por su carácter faccioso y la compleja estructura de sus recursos relacionales ${ }^{2}$.

Las anomalías generalizadas, entre otras causales, habían llevado a una situación crítica que afectó al sistema financiero y derivó en una de las crisis económicas y políticas más profundas de la Argentina moderna ${ }^{3}$.

El proceso investigativo al que aquí nos referimos fue resultado de la decisión del presidente Pellegrini de examinar buena parte de los bancos del país para saber su estado de situación. Poco a poco, y a medida que la misión fue avanzando, lo acaecido en el BPSF, en consonancia con lo registrado en otras instituciones, adquirió cada vez mayor estado público. El caso del BPSF fue uno de los escándalos de corrupción, más importantes, que involucró a personalidades destacadas del mundo político y empresarial. Cabe destacar que el término "escándalo" refiere a aquellos hechos o acciones que generan un fuerte rechazo o indignación en buena parte de la sociedad. Por otra parte, con el vocablo "corrupción", si bien tal como veremos a lo largo del trabajo revistió un carácter polisémico, hizo referencia a ciertas prácticas de abuso de los agentes estatales y bancarios en pos de un beneficio privado ${ }^{4}$.

Pillado en el informe puso al descubierto una serie de anomalías que derivó en la presentación de una denuncia judicial ${ }^{5}$. A la luz de esos acontecimientos, el

\footnotetext{
${ }^{1}$ La misión Pillado. La intervención oportuna. La Capital 29/8/1890.

${ }^{2}$ BONAUDO, Marta. Repensando el partido/facción en la experiencia latinoamericana. Illes i Imperis. Estudios de Historia de las sociedades en el mundo colonial y post-colonial [en línea]. 2015, n. 17, pp. 15-42. [Consulta: 17-05-2020]. Disponible en <https://dialnet.unirioja.es/ejemplar/414735>.

${ }^{3}$ ROCCHI, Fernando. Dossier. La crisis de 1890: política, sociedad y literatura. Introducción. Entrepasados. Revista de Historia [en línea]. 2003, n. 24/25, p. 19. [Consulta: 15-08-2020]. Disponible en <https://ahira.com.ar/ejemplares/entrepasados-no-24-25/>.

${ }^{4}$ THOMPSON, John. El escándalo político: poder y visibilidad en la era de los medios. Barcelona: Paidós Ibérica, 2001; ENGELS, Jens Ivo. La nueva historia de la corrupción. Algunas reflexiones sobre la historiografía de la corrupción política en los siglos XIX y XX. Ayer. Revista de Historia Contemporánea [en línea]. 2019, n. 115, p. 25. [Consulta: 27-09-2020]. Disponible en $<$ http://revistaayer.com/anteriores/1362>.

5 El resultado de ese estudio fue publicado de forma completa bajo el nombre: Intervención Nacional
} 
escándalo del BPSF se propagó en las esferas periodísticas, políticas y parlamentarias ${ }^{6}$.

Desde fines del siglo XX y, especialmente, en las últimas décadas del XXI, al calor de los debates originados dentro de las historiografías europeas y latinoamericanas, en Argentina se han evidenciado una serie de estudios focalizados en la corrupción ${ }^{7}$. Sin embargo, las investigaciones centradas en las denuncias de este tipo en torno a las casas bancarias han sido menores, fundamentalmente, si se

del Banco Provincial de Santa Fé: documentos oficiales, 1890. Buenos Aires: s/d, 1891.

${ }^{6}$ Estos temas han sido abordados en algunos artículos recientes de nuestra autoría: GARCILAZO, Romina. Los escándalos de corrupción retratados por la prensa. El caso del Banco Provincial de Santa Fe (Argentina) segunda mitad del siglo XIX. Anuario Colombiano de Historia Social y de la Cultura [en línea]. 2019, vol. 1, n. 46, pp. 209-230. [Consulta 20-09-2020]. Disponible en $<$ https://revistas.unal.edu.co/index.php/achsc/issue/view/5066>; Voces disidentes en el Parlamento Nacional. Escándalo, corrupción y denuncias cruzadas. Santa Fe (Argentina), últimas décadas del siglo XIX. En: PEÑA GUERRERO, María Antonia y BONAUDO, Marta (dirs.). Historia cultural de la corrupción política. Prácticas, escenarios y representaciones contemporáneas. Rosario: Prohistoria Ediciones, 2019, pp. 89-101; Imágenes, discursos y escándalos de corrupción. El Banco Provincial de Santa Fe 1889-1894. Anuario del Instituto de Historia Argentina [en línea]. 2019, vol. 19, n. 2, pp. 117. [Consulta: 15-09-2020]. Disponible en $<$ https://www.anuarioiha.fahce.unlp.edu.ar/search/authors/view?firstName=Romina\&middleName=\&la stName=Garcilazo\&affiliation=UNR-ISHiR\%2FCONICET\&country=AR>; Empresariado y poder político. El Partido del Pueblo en Santa Fe (Argentina) hacia fines del siglo XIX. Ayer. Revista de Historia Contemporánea [en línea] 2020, n. 118, pp. 49-75. [Consulta: 20-07-2021]. Disponible en $<$ https://revistaayer.com/anteriores/1408>.

7 Véase: GIORDANO, Verónica. La corrupción política en Argentina, 1886-1890. Una mirada desde The Times de Londres. Sociohistórica [en línea]. 2000, n. 7, pp. 251-268. [Consulta: 27-05-2020]. Disponible en <http://www.memoria.fahce.unlp.edu.ar/library?a=d\&c=arti\&d=Jpr2828>; Qué va cha ché. Corrupción y poder político en la Argentina 1890 cien años después. Buenos Aires: Universidad de Buenos Aires, 2003; POMER, León. La corrupción, una cultura argentina. Buenos Aires: Leviatán, 2004; LOTERSZTAIN, Israel. Los Bancos se roban con firmas: corrupción y crisis en 1890. Buenos Aires: Turmalina, 2010; La corrupción política como causa de la crisis bancaria de 1890. Revista de Instituciones, Ideas y Mercados [en línea]. 2016, n. 64-65, pp. 143-165. [Consulta: 07-07-2020]. Disponible en <http://www.eseade.edu.ar/wp-content/uploads/2017/08/6 lotersztain riim64 65.pdf>; ROJKIND, Inés. El triunfo moral del pueblo. Denuncias de corrupción y movilización política en Buenos Aires, a fines del siglo XIX. En: ROSENMÜLLER, Christoph y RUDERER, Sthephan (eds.). "Dádivas, dones y dinero". Aportes a una nueva historia de la corrupción en América Latina desde el Imperio español hasta la modernidad. Madrid: Iberoamericana Vervuert, 2016, pp.169-187; "La revolución está vencida, pero el gobierno está muerto". Crisis política, discursos periodísticos y demostraciones callejeras en Buenos Aires, 1890. Anuario de Estudios Americanos [en línea]. 2012, vol. 2, n. 69, pp. 507-532. [Consulta: 15-7-2020]. Disponible en $<$ https://estudiosamericanos.revistas.csic.es/index.php/estudiosamericanos/article/view/578>;

HIRSCH, Leandro. "Prensa independiente" y crítica moral al juarismo (1889-1890). Estudios Sociales [en línea]. 2013, n. 44, pp. 73-100. [Consulta: 7-06-2020]. Disponible en $<$ https://dialnet.unirioja.es/servlet/articulo?codigo=7624329>; RUDERER, Sthephan. Corrupción y violencia. Una relación ambivalente en Argentina y Uruguay en el siglo XIX. En: ROSENMÜLLER, Christoph y RUDERER, Sthephan (eds.). "Dádivas, dones y dinero". Op. cit.; ROMERO, Ana Leonor. El "escándalo Magnasco". Denuncia pública y controversia sobre el papel del Congreso en la Argentina del 1900. Jahrbuch für Geschichte Lateinamerikas /Anuario de Historia de América Latina [en línea]. 2019, n. 56, pp. 232-254. [Consulta: 15-7-2020]. Disponible en <https://journals.sub.unihamburg.de/hup1/jbla/article/view/147>; BONAUDO, Marta. 1889/1893 ¿Un nuevo umbral de la percepción de la corrupción política? En: PEÑA GUERRERO, María Antonia y FERIA LORENZO, Diego (dirs.). Corrupción política y liberalismo en el largo siglo XIX. Granada: Comares Historia, 2020, pp. 101-117; GARCILAZO, Romina. Los escándalos de corrupción... Op. cit.; Voces disidentes... Op. cit.; Imágenes, discursos y escándalos... Op. cit. 
tiene en cuenta lo acontecido en el interior del país ${ }^{8}$.

Creemos que profundizar en este tópico resulta significativo en varios sentidos. El primero, porque la banca ha sido uno de los espacios privilegiados a partir de los cuales se entramaron una serie de vínculos entre empresarios, directivos y grupos políticos que derivaron en denuncias sobre la apropiación indebida de recursos estatales $^{9}$. El segundo, se debe a que los escándalos bancarios fueron uno de los ejes a partir de los cuales se acusó al Autonomismo provincial de incurrir en prácticas ilícitas. El tercero, se relaciona con que, a partir de él, podemos arrojar luz sobre algunos de los puntos que hoy inquietan a la llamada "Nueva" Historia Cultural de la Corrupción Política - vertiente que ha tenido en estos últimos años un importante desarrollo en la historiografía europea y en menor medida en la latinoamericana - como aquel que pivota en torno a los discursos que confluyen sobre el mencionado término y las percepciones que los protagonistas de las denuncias esgrimen respecto a los hechos escandalosos ${ }^{10}$. Asimismo, a partir de este tipo de denuncias nos acercaremos a la vinculación entre procesos investigativos, derivación judicial e influencia periodística. Los estudios referidos a dichas temáticas han evidenciado, por un lado, las dificultades que existen para sancionar a quienes incurren en delitos $\mathrm{y}$, por otro, el rol nodal que ha tenido la prensa en la difusión, el reflejo y la promoción de los escándalos ${ }^{11}$.

El hecho de mirar dichos problemas tomando como epicentro el informe elaborado por Pillado tiene sus razones. Hasta el momento las denuncias de corrupción en torno al BPSF habían provenido de la prensa, principalmente, opositora al oficialismo. A partir de la misión y mediante el proceso investigativo, las acusaciones se originaron desde la misma esfera gubernamental y culminaron en la justicia. Ello demuestra, parafraseando a Jens Ivo. Engels, que los márgenes de tolerancia sobre las prácticas corruptas ya no solo inquietaban a los sectores periodísticos, sino también al ámbito estatal ${ }^{12}$. En este sentido, el caso se inscribe en ese clima de época que se abrió en la Argentina en 1890, y que Marta Bonaudo, retomando las ideas del autor anteriormente mencionado, caratuló como un

\footnotetext{
${ }^{8}$ LOTERSZTAIN, Israel. Los bancos se roban... Op. cit.; BOIXAIDÓS, Cristina. El financiamiento de la expansión urbana a través de la documentación del Banco de la provincia de Córdoba 1880/1895. Revista de Economía y Estadística. 1986-1989, n. 27, pp. 1-32; GARCILAZO, Romina. Los escándalos de corrupción... Op. cit.; Voces disidentes... Op. cit.; Imágenes, discursos y escándalos... Op. cit.

${ }^{9}$ NEWLAND, Carlos. Clase política y sector bancario en la Argentina de entreguerras: el caso del Banco Español y del Río de la Plata. América Latina en la Historia Económica [en línea]. 2020, vol. 2, n. 27, pp. 2 y $13 . \quad$ [Consulta 20-8-2020]. Disponible en $<$ http://alhe.mora.edu.mx/index.php/ALHE/article/view/e1028>.

${ }^{10}$ Sobre este tema, véase: RESENMÜLLER, Cristoph y RUDERER, Sthephan (eds "Dádivas, dones y dinero". Op. cit.; PEÑA GUERRERO, María Antonia y BONAUDO, Marta (dirs.). Historia cultural de la corrupción... Op. cit., pp. 35-51.

${ }^{11}$ En relación a estos tópicos, consúltese: RIQUER, Borja [et al.] (dirs.). La corrupción política en la España Contemporánea. Un enfoque interdisciplinar. Madrid: Marcial Pons, 2018 MONIER, Frédéric. ¿Un "régimen honesto"? Soberanía y virtud en la República Francesa (1870-1940). Ayer. Revista de Historia Contemporánea [en línea]. 2019, n. 115, pp. 51-75. [Consulta: 29-09-2020]. Disponible en $<$ http://revistaayer.com/anteriores/1362>; PEÑA GUERRERO, María Antonia y BONAUDO, Marta (dirs.). Historia Cultural... Op. cit.; RIQUER, Borja. Cambó en la Argentina. Negocios y corrupción política. Buenos Aires: Edhasa, 2016.

${ }^{12}$ ENGELS, Jens Ivo. La nueva historia de la corrupción... Op. cit., pp. 28-29.
} 
momento de corrimiento del umbral de la admisibilidad social respecto al hecho corrupto $^{13}$.

El estudio se extiende desde 1890, momento en que se inicia la tarea emprendida por Pillado, hasta 1894, año en que en las cámaras legislativas nacionales y en la opinión pública las anomalías del BPSF fueron objeto de disputa política entre autonomistas y opositores. Desde 1890, la Unión Cívica, luego fraccionada en Unión Cívica Nacional y Unión Cívica Radical, fue la principal fuerza opositora al Autonomismo. Su discurso apeló a la defensa de la pureza del sufragio y la moral administrativa ${ }^{14}$.

Algunas de las preguntas que guían el presente artículo son las siguientes: ¿Qué términos vinculados al concepto de corrupción fueron empleados por el enviado gubernamental? ¿Qué rol jugó la prensa en el proceso investigativo? ¿Qué percepciones tuvieron los protagonistas de los escándalos respecto a los hechos? ¿Cuáles fueron las derivaciones judiciales, políticas y sociales del informe presentado?

Por último, cabe destacar que en este trabajo utilizamos un conjunto de insumos documentales que lo sustentan: el Informe presentado en 1890 por Pillado al gobierno nacional, obras de época, estatutos, leyes y acuerdos referentes al BPSF, debates parlamentarios e información periodística vertida por dos de los principales diarios de mayor circulación en la ciudad de Rosario -epicentro de las denunciasLa Capital y El Municipio.

\section{Corrupción, escándalo, denuncia e investigación}

Antes del siglo XIX, el término corrupción -en uno de sus usos más extendidos- refería a la declinación de la virtud tanto de políticos como de instituciones públicas ${ }^{15}$. Las modificaciones impuestas -a partir del 1800 - en la normativa pública afectaron la concepción que se tenía de dicho vocablo. Ello se debió a que, poco a poco, en el escenario europeo se impusieron ordenamientos unívocos sobre la administración pública en los que se privilegió la defensa del bien común. Así, se produjo, desde la teoría, una separación nítida entre lo público y privado, aunque en la práctica esos límites fueron más difusos. Paralelamente, se evidenció una mayor preocupación estatal por controlar a las personas que ejercían tareas gubernamentales. En este contexto, la corrupción devino en acusación. Desde ese momento, los funcionarios que no respetaran las reglamentaciones estaban obligados a negar sus acciones defendiéndose de los cargos atribuidos ${ }^{16}$. De este modo, siguiendo las ideas de Engels, en la contemporaneidad, la

\footnotetext{
${ }^{13}$ BONAUDO, Marta. 1889/1893... Op. cit., pp. 101 y 117.

${ }^{14}$ ALEM, Leandro [et al.]. Manifiesto de la Junta Revolucionaria (1890). En: BOTANA, Natalio y GALLO, Ezequiel. De la República posible a la República verdadera (1880-1910). Buenos Aires: Ariel Historia, 1997, pp. 231-235; PERSELLO, Ana Virginia. Historia del Radicalismo. Buenos Aires: Edhasa, 2007, p. 41.

${ }^{15}$ ENGELS, Jens Ivo. Corruption and Anticorruption in the Era of Modernity and Beyond. En: KROEZE, Ronald [et al.] (eds.). Anticorruption in History. From Antiquity to the Modern Era. Oxford: Oxford University Press, 2018, p. 169.

${ }^{16}$ ENGELS, Jens Ivo. La "modernidad" de la corrupción. En: PEÑA GUERRERO, María Antonia y BONAUDO, Marta (dirs.). Historia Cultural... Op. cit., pp. 22, 25 y 27.
} 
corrupción, en principio, resultaba injustiblicable ${ }^{17}$. Estas concepciones explican por qué dichas prácticas dejaron de estar circunscriptas al ámbito secreto para irrumpir en la esfera pública forjando "el escándalo". ${ }^{18}$

Generalmente, aunque no siempre, las denuncias de corrupción devienen en escándalos ${ }^{19}$. Entre sus temáticas - aunque la corrupción tuvo un lugar centralfiguraban diversos tópicos relacionados, por ejemplo, a cuestiones raciales, sexuales y diplomáticas ${ }^{20}$. Hacia el 1900 , ellos estuvieron determinados por el importante peso que los medios de comunicación tuvieron en la difusión, revelación y publicación de los hechos ${ }^{21}$. El periodismo fue un actor clave, en tanto que, a través de la publicidad divulgó — de una forma rápida y amplia - las noticias de esta naturaleza al conjunto social. Sin embrago, este tipo de hechos trascendió ampliamente el espacio periodístico llegando a los ámbitos políticos y judiciales ${ }^{22}$.

Asimismo, algunos escándalos podían derivar en investigaciones emprendidas por la prensa y los órganos parlamentarios ${ }^{23}$. Con respecto a este último punto, para el caso argentino, hemos observado que las indagaciones fueron vehiculizadas por el Congreso Nacional - a principios de la década de 1890 - cuando involucraban a ministros del poder ejecutivo y por el gobierno central -en los años que siguieron al golpe de Estado en 1955- en circunstancias que referían a denuncias de corrupción durante la gestión del presidente Juan D. Perón (1946-1955) ${ }^{24}$. También, fueron llevadas a cabo por los poderes locales o provinciales, por ejemplo, cuando las sospechas de corrupción tenían como protagonistas a las empresas extranjeras de servicios públicos que operaban en complicidad con la clase política. Paralelamente, los procedimientos fueron acompañados por manifestaciones populares ${ }^{25}$.

Algunos de esos procesos concluyeron en acciones judiciales que llevaron a la detención -temporaria- de los personajes sospechados ${ }^{26}$. Si bien, en Argentina, para este período existió un cuerpo legal que penalizó algunos delitos de corrupción

\footnotetext{
${ }^{17}$ Esta idea ha sido recuperada del texto de MONIER, Frédéric. La corruption injustificable: debats publics, practiques de pouvoir, cultures politiques (XIXe-XXe siècles). Seminaire de philosophie du droit, Institut des hautes études sur la justice. París, 2014, p. 2.

${ }^{18}$ PEÑA GUERRERO, María Antonia y BONAUDO, Marta. Presentación. En: PEÑA GUERRERO, María Antonia y BONAUDO, Marta (dirs.). Historia Cultural... Op. cit., p. 12.

19 PEREYRA, Sebastián. Política y transparencia. La corrupción como problema público. Buenos Aires: Siglo Veintiuno, 2013, p. 142.

${ }^{20}$ Ibídem.

21 DALMAU, Pol y BURDIEL, Isabel. Presentación. Imagen pública del poder. Escándalos y causas célebres en Europa (siglos XIX-XX). Historia y Política: ideas, procesos y movimientos sociales [en línea]. 2018, n. 39, p.19. [Consulta: 27-04-2020]. Disponible en <https://dialnet.unirioja.es/ejemplar/485413>

${ }^{22}$ MONIER, Frédéric. ¿Un "régimen honesto"?... Op. cit., p. 60.

${ }^{23}$ MONIER, Frédéric. ¿Un "régimen honesto"?... Op. cit., p. 64.

${ }^{24}$ BALESTRA, Juan. El noventa. Una evolución política argentina. Buenos Aires: Hyspamérica, 1986; ROMERO, Ana Leonor. El "escándalo Magnasco"... Op.cit., p. 249; FERREYRA, Silvana. Usos políticos de la corrupción en el enfrentamiento peronismo-antiperonismo. Una lectura desde las comisiones investigadoras en 1955 en Argentina [en línea]. Barcelona: Institut de Ciencies Politiques i Socials, Adscrit a la Universitat Autónoma de Barcelona, 2019. [Consulta: 23-04-2020]. Disponible en $<$ https://www.icps.cat/archivos/Workingpapers/wp356.pdf>.

${ }^{25}$ RIQUER, Borja. Cambó en la Argentina...Op. cit., pp. 258-259 y 529.

${ }^{26}$ RIQUER, Borja. Cambó en la Argentina...Op. cit., p. 326.
} 
como el cohecho y la malversación de dineros públicos resultó infrecuente que los funcionarios fuesen denunciados judicialmente. Este rasgo ha sido más bien una constante en el país ${ }^{27}$. En parte, ello se debe a las actitudes con que la clase gobernante ha enfrentado el tema, a los vacíos normativos respecto a la cuestión penal, a la dificultad probatoria que recubren los hechos de corrupción y a que ciertas acciones espurias no se encuentran debidamente sancionadas ${ }^{28}$.

Tal como se dijo anteriormente, durante el gobierno de Pellegrini, se llevaron a cabo diferentes pesquisas gubernamentales en las entidades bancarias del país. Pese a la evidencia que muchas de ellas lograron reunir, no todas desencadenaron en acciones judiciales ${ }^{29}$. En este sentido, el caso del BPSF resulta significativo. Además, mientras que algunas denuncias radicadas en Buenos Aires en contra de las casas bancarias fueron más bien silenciadas y los personajes involucrados no perdieron su consideración social, lo ocurrido en el BPSF demuestra lo contrario ${ }^{30}$.

\section{Los escándalos de corrupción investigados. La Misión Pillado en el BPSF}

La banca argentina —a principios de la década de 1890 - se encontró en una situación sumamente compleja. Esto, en parte, se debió a algunas de las medidas tomadas por el presidente Juárez Celman como la aplicación de la Ley de Bancos Garantidos. Dicha normativa se enmarcó en un proyecto político mayor que tuvo por objetivo dotar a las entidades de todo el país de la facultad de emitir moneda a través de la compra de bonos estatales que oficiaran de respaldo ${ }^{31}$. La mala aplicación de la reglamentación por parte del gobierno y las anomalías bancarias provocaron que la emisión se realizara de manera descontrolada ${ }^{32}$. Estos componentes estuvieron entre las causales de la crisis de 1890.

Luego, de ella se reestructuró el sistema financiero como consecuencia de su propio colapso. En este escenario, el Banco de la Provincia de Buenos Aires - la entidad más próspera del país- fue uno de sus actores protagónicos ${ }^{33}$. El reordenamiento del sistema bancario se erigió sobre las ruinas del Banco Nacional,

\footnotetext{
${ }^{27}$ GIORDANO, Verónica. La corrupción política... Op. cit., p. 254; MONIER, Frédéric. ¿Un "régimen honesto"?... Op. cit., pp. 64-65; PEÑA GUERRERO, María Antonia y BONAUDO, Marta. Presentación...Op. cit., p. 13.

${ }^{28}$ GIORDANO, Verónica. Qué va cha ché... Op. cit., p. 16; VITELLI, Guillermo. La corrupción como producto de los procesos históricos y de las lógicas de las estructuras político-económicas. En: Congreso Latinoamericano de Historia Económica. México: Centro Cultural Universitario Tlatelolco, 2010, p. 13.

${ }^{29} \mathrm{Si}$ bien los especialistas han hecho referencia a las investigaciones gubernamentales llevadas a cabo en entidades como el Banco Nacional o el Banco de Córdoba, no se tienen datos acerca de si ellas derivaron en acciones judiciales. BOIXAIDÓS, Cristina. El financiamiento de la expansión... Op. cit.; POMER, León. La corrupción... Op. cit.; LOTERSZTAIN, Israel. Los bancos se roban... Op. cit.; La corrupción política... Op. cit.

${ }^{30}$ LOTERSZTAIN, Israel. Los bancos se roban... Op. cit., pp. 99-100.

31 Argentina. Ministerio de Hacienda. Bancos de Emisión y Hacienda Pública. Buenos Aires: La Tribuna Nacional, 1889, p. 205.

32 ROCCHI, Fernando. El péndulo de la riqueza: la economía argentina 1880-1916. En: LOBATO, Mirta Zaida (dir.). El progreso, la modernización y sus límites (1880-1916). Buenos Aires: Sudamericana, 2000, p. 40.

${ }^{33}$ GERCHUNOFF, Pablo; ROCCHI, Fernando y ROSSI, Gastón. Desorden y progreso. Las crisis económicas argentinas 1870-1905. Buenos Aires: Edhasa, 2008, p. 14.
} 
entidad sobre la cual se estructuró el sistema monetario y crediticio del período y que ofició de agente financiero exterior del Estado Nacional ${ }^{34}$. Este sufrió fuertemente los embates ya que las reservas en oro de los bancos garantidos - que debían ser depositadas en sus arcas como respaldo de la emisión- fueron notoriamente menores ${ }^{35}$. Esos acontecimientos provocaron una depreciación del papel moneda, la suba del valor del oro y un proceso inflacionario ascendente que se intensificó por las conductas especulativas de los agentes que actuaron en el mercado bursátil e inmobiliario $^{36}$. Por otra parte, los clientes de los bancos provinciales e hipotecarios ante la situación de pánico- extrajeron buena parte de sus depósitos ${ }^{37}$. En ese complejo escenario, una de las medidas de Pellegrini fue intervenir la totalidad de los bancos provinciales y el Banco Nacional ${ }^{38}$.

Cabe recordar que el BPSF se fundó —en 1874- como una sociedad anónima de capitales mixtos cuyo mayor accionista fue el Estado provincial -el capital inicial aportado provino de un crédito externo otorgado en el mercado londinense- $y$, en menor medida, un grupo de empresarios de destacada trayectoria ${ }^{39}$. La estrecha vinculación entre la clase política santafesina y los directivos de la entidad fue una constante que se mantuvo a lo largo del tiempo. Durante la gestión de Gálvez, la entidad fue cuestionada por ser uno de los espacios - junto a la obra pública y la venta de terrenos fiscales- a partir del cual los miembros del poder político y económico local se enriquecieron ${ }^{40}$.

El BPSF tuvo su asiento principal en Rosario y varios anexos en la ciudad capital y en el interior provincial ${ }^{41}$. Durante la presidencia de Juárez Celman, fue incorporado a la Ley de Bancos Garantidos, conservando el dinamismo experimentado desde sus inicios debido a la pujante situación económica de Santa $\mathrm{Fe}$, uno de los epicentros del modelo agroexportador argentino. Las principales funciones del BPSF fueron la emisión de billetes, el otorgamiento de créditos al sector mercantil, industrial y agrícola y la contratación de empréstitos con el gobierno

\footnotetext{
${ }^{34}$ MARICHAL, Carlos. Historia de la deuda externa en América Latina. México: Alianza Editorial Mexicana, 1988.

${ }^{35}$ LOTERSZTAIN, Israel. La corrupción política... Op. cit., p. 146.

${ }^{36}$ MARICHAL, Carlos. Historia de la deuda... Op. cit., pp. 164-165.

37 TERRY, José. La crisis 1885-1892: sistema bancario. Buenos Aires: Imprenta Biegma, 1893, pp. 190-191.

${ }^{38}$ GERCHUNOFF, Pablo; ROCCHI, Fernando y ROSSI, Gastón. Desorden y progreso... Op. cit., p. 169; LOTERSZTAIN, Israel. La corrupción política... Op. cit., p. 147.

39 GALLO, Ezequiel. El gobierno de Santa Fe vs. El Banco de Londres y Río de la Plata (1876). Revista Latinoamericana de Sociología. 1971, vol. 2/3, n. 7, p. 152; BONAUDO, Marta y SONZOGNI, Elida. Empresarios y poder político en el espacio santafesino (1860-1890). Carlos Casado y su estrategia de acumulación. Historia y Grafía. 1998, n. 11, pp. 39-64.

${ }^{40}$ ¿Cómo se ha gobernado Santa Fe? ¿Quiénes saquearon el Banco Provincial? Autopsia de la política santafecina. La Capital. 29/8/1894. DE MARCO, Miguel Ángel. El contralor del Estado en la transformación argentina. Tierras, ferrocarriles y obras públicas en Santa Fe. Rosario: Universidad Católica Argentina, 2002, p. 38.

${ }^{41}$ Ministerio de Hacienda, Justicia y Obras Públicas. Don Presidente del Banco Provincial del Rosario, solicita autorización para deducir terciaria de dominio excluyente del edificio que ocupa decretado por la Corte Suprema. Santa Fe: s/d, 1898; Banco Provincial de Santa Fe. Leyes referentes al Banco Provincial de Santa Fe. Santa Fe: s/d, 1895, p. 5; DALLA-CORTE CABALLERO, Gabriela. Lealtades firmes. Redes de sociabilidad y empresas: <La Carlos Casado S.A> entre la Argentina y el Chaco Paraguayo (1860-1940). Madrid: Consejo de Investigaciones Científicas, 2009, pp. 70-71.
} 
provincial y los estados locales ${ }^{42}$.

En agosto de 1890, el BPSF fue investigado por el comisionado Pillado. Esta acción se enmarca en un proceso político y económico mayor llevado a cabo por el presidente Pellegrini para dar respuesta a la compleja situación de las instituciones financieras del Estado. En ese contexto, una de las primeras medidas del ejecutivo fue la firma de un decreto que estableció la intervención de los bancos provinciales $^{43}$. Para el cumplimiento de esa tarea se procedió al nombramiento de comisionados. Si bien se cuentan con pocos datos biográficos, se sabe que Pillado fue una personalidad con amplios conocimientos en el mundo de las finanzas ${ }^{44}$. Quizás su prolífica obra escrita sobre temas comerciales y bancarios es una muestra evidente de su grado de especialización en la esfera económica ${ }^{45}$.

El agente estatal tenía la tarea de informar al ejecutivo nacional, entre otros puntos, sobre el estado de la emisión, la existencia de sus reservas en oro, la nómina de su cartera de clientes, la configuración de su capital bancario y el proceder de su personal administrativo ${ }^{46}$.

Durante su estadía en la provincia de Santa Fe — que duró poco menos que dos meses- Pillado recuperó toda la información solicitada y se reunió con políticos locales y autoridades bancarias. Para ello contó con la asistencia de una comisión interventora nombrada —-mediante decreto - por el poder ejecutivo e integrada por Elías Alvarado, José Leguizamón y Ángel Díaz. Paralelamente, mantuvo una comunicación estrecha y permanente con el Ministro de Hacienda de la Nación. Su labor derivó en la presentación de dos escritos ante la Justicia Federal debido a que ciertas conductas de los administradores de la entidad eran punibles. Entre estas últimas, se destacaron: la adulteración de billetes, la inexistencia del encaje metálico declarado, el otorgamiento de abultados créditos al director del BPSF, al Gobierno de la Provincia y a un conjunto de particulares y la presentación de informes ficticios por parte del directorio ${ }^{47}$. Algunas de estas anomalías también se visualizaron en otras entidades bancarias durante la vigencia de la Ley de Bancos Garantidos. Por ejemplo, los especialistas han comprobado el otorgamiento de créditos preferenciales al interior de los directorios del Banco Nacional y Banco de Córdoba ${ }^{48}$.

\footnotetext{
${ }^{42}$ Banco Provincial de Santa Fe. Leyes referentes al Banco Provincial de Santa Fe... Op. cit., p. 7.

${ }^{43}$ GERCHUNOFF, Pablo; ROCCHI, Fernando y ROSSI, Gastón. Desorden y progreso... Op. cit., p. 169.
}

${ }_{44}$ El señor Ricardo Pillado. El Municipio [en línea]. 4/9/1890. Disponible en $<$ https://biblio1.rosario.gob.ar/cgi-bin/koha/opacsearch.pl?q=El+Municipio+1890\&branch group limit=>.

${ }^{45}$ Entre sus trabajos se destacan: Anuario Pillado de la deuda pública y sociedades anónimas establecidas en la República Argentina para 1899. Buenos Aires: La Nación, 1899; comercial argentina contribución a su estudio. Buenos Aires: Talleres de publicaciones de la Oficina meteorológica argentina, 1906; Comentarios sobre los tratados de comercio argentinos. Buenos Aires: Talleres Gráficos del Ministerio de Agricultura, 1915.

${ }^{46}$ PILLADO, Ricardo. Intervención Nacional... Op. cit., p. 3. Sobre los resultados de la investigación llevada a cabo por el comisionado de gobierno en el Banco Provincial de Córdoba, véase: BOIXAIDÓS, Cristina. El financiamiento 1986-1989... Op. cit.

${ }^{47}$ PILLADO, Ricardo. Intervención Nacional... Op. cit., pp. 32; 40-48; 54-60.

${ }^{48}$ BOIXAIDÓS, Cristina. El financiamiento 1986-1989... Op. cit.; LOTERSZTAIN, Israel. La corrupción política... Op. cit., p. 149. 
Finalmente y después de un tiempo, el gobierno nacional decretó el cese de la intervención de todos los bancos provinciales del territorio. La decisión del ejecutivo se sustentó en la creencia de que la misión gubernamental había cumplido con su objetivo fundamental: acordar con las entidades la negociación del servicio de los empréstitos exteriores. Pese a que las causas judiciales que envolvieron al BPSF no tuvieron pronta resolución el tema quedó instalado y fue recuperado por buena parte de la sociedad ${ }^{49}$. No era para menos. Se había comprobado —mediante un proceso investigativo- que aquellas acusaciones pronunciadas por la prensa opositora al Autonomismo, desde hacía tiempo, no habían sido meras habladurías. El informe presentado no era producto de las pasiones evidenciadas en las reyertas políticas y periodísticas, sino que provenía de la esfera estatal al mando de quien había sido el vicepresidente de Juárez Celman. Sobre estos hechos El Municipio enfatizó:

"[...] es la primera vez también que se denuncia á los tribunales sin temores ni escrúpulos, los escándalos que pueden traducirse en crímenes $[\ldots]^{50}$.

Por último, cabe recordar que, pese al estado endeble en el que se encontró el BPSF a inicios de la década de 1890, poco a poco, fue mejorando su situación. Mediante un largo y difícil proceso la entidad fue reorganizada, algunos de sus clientes honraron las deudas que mantenían con él y sus compromisos en el exterior fueron renegociados ${ }^{51}$.

\section{Investigación y prensa}

El periodismo ocupó un rol central, tal como ya se ha dicho, en la difusión de los escándalos. Particularmente, el espacio noticioso de los años $90^{\prime}$, y en especial en lo concerniente a las denuncias de corrupción durante la administración de Juárez Celman, se erigió como un referente político e ideológico. La prensa tuvo un fuerte impacto en la población forjando en ella una cierta idea común sobre la necesidad de emprender una tarea de reparación moral y política ${ }^{52}$.

En Rosario, los dos matutinos de mayor circulación — La Capital y El Municipiodedicaron numerosos editoriales al respecto. El Municipio, particularmente, se destacó por la sagacidad de sus crónicas noticiosas teñidas, además, del fuerte antigalvismo confeso de su director Deolindo Muñoz. Por su parte, La Capital -si bien tuvo una prosa más cautelosa - no por ello dejó de denunciar, de manera constante, los hechos evidenciados en el BPSF. Ovidio Lagos, su mentor, también

\footnotetext{
${ }^{49}$ PILLADO, Ricardo. Intervención Nacional... Op. cit., pp. 67; 40. Congreso de la Nación. Diario de sesiones de la Cámara de Senadores: Buenos Aires: Establecimiento Topográfico "El Comercio", 1894 , p. 301.

${ }^{50}$ El asunto del día. Lo del Banco Provincial ¡Pasó a la justicia!. El Municipio [en línea]. 11/10/1890. Disponible en <https://biblio1.rosario.gob.ar/cgi-bin/koha/opacsearch.pl?q=El+Municipio+1890\&branch group limit>.

${ }^{51}$ Ministerio de Hacienda. Reorganización del Banco Provincial de Santa Fe: mensaje presentado por el Poder Ejecutivo de la provincia a las Honorables Cámaras legislativas por Santa Fe. Santa Fe: Topografía La Tribuna Popular, 1894; Ministerio de Hacienda, Justicia y Obras Públicas. Banco Provincial (Rosario) arreglo de deuda de D, Juan Canals. Rosario: s/d,, 19 de febrero de 1899, f. 142.

${ }^{52}$ ROJKIND, Inés. La revolución está vencida... Op. cit., pp. 521; 528; El triunfo moral... Op. cit., p. 176.
} 
perteneció —durante el desarrollo de los escándalos - a las filas opositoras del Autonomismo provincial siendo uno de los líderes del Partido Constitucional. Aunque, luego acordó una alianza política con el sector liderado por el presidente Julio A. Roca (1880-1886/1898-1904) ${ }^{53}$. En este sentido, es razonable que la misión Pillado ocupara un lugar central en la columna de los diarios y que haya sido recibida con beneplácito. Incluso, algunos miembros del oficialismo le otorgaron a la prensa una influencia mayor en los acontecimientos ${ }^{54}$.

La anuencia del periodismo respecto a la investigación radicó en las propias cualidades de Pillado, ya que — tal como hemos visto- era un hombre especializado en el área financiera, y en la importancia que ella revistió ${ }^{55}$. Así, con percepciones convergentes, La Capital sostuvo que la tarea era una "cruzada redentora"56 a la vez que, El Municipio argumentó que esta era una obra moral ${ }^{57}$. La primera de las ideas se asoció con las concepciones de la época sostenidas por los detractores del juarismo sobre la necesidad de apartar y contrarrestar todas las calamidades en la que se encontraba sumido el país y la obligación de emprender una acción reparadora ${ }^{58}$. Por su parte, El Municipio introducía el concepto de "moralidad". Al respecto, sabemos que en la lengua castellana el vocablo corrupción estaba asociado, entre otros términos, a la desmoralización ${ }^{59}$. De este modo, la tarea de Pillado era una pieza más de las acciones que debían llevarse a cabo para regenerar la arena política y salvaguardar los dineros públicos ${ }^{60}$. Desde luego, ella suponía el desenmascaramiento de aquellos negociantes que habían actuado sin conciencia y la restitución del crédito del banco en pos del desarrollo comercial e industrial de la región ${ }^{61}$.

En algunos momentos, la prensa operó como una fuente de información a partir de la cual Pillado recabó datos sobre el BPSF y orientó sus acciones posteriores. En un telegrama enviado al Ministro de Hacienda de la Nación el comisionado sostenía: "[...] además un diario de la tarde 'El Mensajero' asegura que el Banco ha suspendido pagos. Hoy comenzaré mi inspección [...]"62. Asimismo, en otras instancias, Pillado se sintió interpelado por la información que circuló en los diarios locales y en los círculos políticos. Esta fue tomada en cuenta por él para trazar el armado de la futura administración bancaria. En una de sus comunicaciones con

${ }^{53}$ BONAUDO, Marta. De representantes y representados: Santa Fe finisecular (1883-1893). En: SABATO, Hilda (coord.). Ciudadanía política y formación de las naciones. Perspectivas históricas de América Latina. México: Fondo de Cultura Económica, 1999, p. 282.

${ }^{54}$ Congreso de la Nación. Diario de sesiones de la Cámara de Diputados. Buenos Aires: Imprenta del "Congreso", 1894, p. 624.

${ }^{55}$ La misión Pillado. La intervención oportuna... Op. cit; El señor Ricardo Pillado... Op. cit.

${ }_{57}^{56}$ La misión Pillado. La intervención oportuna... Op. cit.

57 El asunto del Banco Provincial. El Municipio [en línea]. 25/10/1890. Disponible en $<$ https://biblio1.rosario.gob.ar/cgi-bin/koha/opacsearch.pl?q=El+Municipio+1890\&branch group limit $=>$.

${ }^{58}$ ROJKIND, Inés. El triunfo moral... Op. cit., p. 186.

${ }^{59}$ Esta idea se encuentra presente en algunos diccionarios de época de la lengua castellana. Véase: PEÑA GUERRERO, María Antonia y BONAUDO, Marta. Presentación... Op. cit., pp. 10-11.

${ }^{60} \mathrm{HIRSCH}$, La prensa independiente... Op. cit., p. 97.

${ }^{61}$ La misión Pillado. La intervención oportuna... Op. cit.; Inspección al Banco Provincial. El Municipio [en líne] 29/8/1890. Disponible en <https://biblio1.rosario.gob.ar/cgi-bin/koha/opacsearch.pl?q=El+Municipio+1890\&branch group limit=>.

${ }^{62}$ PILLADO, Ricardo. Intervención Nacional... Op. cit., pp. 19-20. 
Fidel López el enviado gubernamental aseveró:

"[...] pero creo que con lo expresado basta para justificar la medida que propongo V.E, esto es, que el Banco sea intervenido por un directorio, de tres personas, cuya honorabilidad y carácter [...] lo constituya en un gobierno del Banco, intachable no solamente para las exigencias legítimas del comercio y del pueblo, sinó [sic] aun ante las opiniones políticas y partidistas [... $]^{163}$.

Según Pillado, el periodismo también tenía cierta cuota de responsabilidad ante el descrédito general que envolvía a la institución. Sobre el BPSF, el comisionado afirmó: "[...] Tal como hoy se halla librado á sus propias fuerzas y á las ardientes batallas que contra él libra la prensa diaria su caída es segura y con ella el desastre consiguiente $[\ldots]^{364}$.Este aspecto pone en evidencia una de las caras de los escándalos de corrupción, es decir, el impacto que las acusaciones revisten en la reputación de las instituciones a las que refieren ${ }^{65}$. La imagen del BPSF — construida por la prensa - tuvo implicancias directas en su propio funcionamiento interno a su situación endeble se sumó el descrédito de sus clientes que —en algunos casosoptaron por el retiro de sus depósitos ${ }^{66}$.

En otras instancias, Pillado interactuó de manera estrecha con el periodismo. Por momentos, apeló a él cuando sintió que este había vulnerado el grado de confidencialidad que su propia tarea requería. Mientras que los editorialistas de $\mathrm{La}$ Capital fueron más respetuosos -en la difusión de ciertos datos- el director de $E I$ Municipio debió responder públicamente las observaciones que el propio comisionado le realizó ${ }^{67}$. En septiembre de 1890 , el matutino difundió una carta escrita por Pillado y dirigida a Muñoz. En ella el comisionado expresó:

"[...] Quiera Vd. tener la deferencia de hacer constar, publicando esta carta, que no solamente no he transmitido á $\mathrm{Vd}$. dato alguno sobre el asunto, sino que había anticipado ya á un caballero que me visitó en nombre de esa Dirección [...] que la reserva de esta comisión, la conceptuaba mi deber y mi decoro como imprescindible á su honesto cumplimiento $[\ldots]^{\prime \prime 68}$.

Esa interpelación generó un cierto malestar en la prensa local. Después de la difusión del escrito Muñoz le respondió a Pillado recordándole que el diario conocía -más que nadie - los pormenores del BPSF porque, sistemáticamente, venía denunciado lo sucedido en la entidad. Por otra parte, el periodista desafió al comisionado a que concurriera a las oficinas de El Municipio en caso de que le fuera necesario: "[...] amplios detalles del manejo de ese establecimiento [...]"69.

\footnotetext{
${ }^{63}$ PILLADO, Ricardo. Intervención Nacional... Op. cit., p. 11.

${ }^{64}$ PILLADO, Ricardo. Intervención Nacional... Op. cit., p. 30.

65 DALMAU, Pol. La reputación del notable. Escándalos y capital simbólico en la España Liberal. Historia y Política: ideas, procesos y movimientos sociales [en línea]. 2018, n. 39, p. 85. [Consulta: 2704-2020]. Disponible en <https://dialnet.unirioja.es/ejemplar/485413>; DALMAU, Pol y BURDIEL, Isabel. Presentación...Op. cit., p. 21.

${ }^{66}$ PILLADO, Ricardo. Intervención Nacional... Op. cit., p. 11.

${ }^{67}$ La misión Pillado. Entrega de los bonos. Clandestinos en puerta. Pillado en el Rosario. La Capital. $4 / 9 / 1890$

${ }^{68}$ PILLADO, Ricardo. Intervención Nacional... Op. cit., p. 25. La carta fue publicada por el diario en cuestión, el 6 de septiembre de 1890, con el título: Carta del señor Pillado.

69 Carta del señor Pillado. El Municipio [en línea]. 6/9/1890. Disponible en
} 
Años después, de culminada su tarea investigativa Pillado, nuevamente, hizo declaraciones públicas a la prensa. Pero esta vez, fue para defenderse de las acusaciones vertidas por el legislador nacional Federico Llobet —que cuestionó la credibilidad del informe presentado- en el Congreso Nacional ${ }^{70}$. En esa oportunidad, el comisionado no solo sostuvo todo lo expuesto allí, sino que aprovechó la oportunidad para solicitar, públicamente, a la justicia que no olvidara el tema y se expidiera al respecto ${ }^{71}$.

Por todo lo dicho anteriormente, observamos que las actitudes de Pillado ilustran cómo los protagonistas y/o partícipes de las denuncias de corrupción se vieron envueltos en los escándalos publicitados por la prensa. El comisionado, ante las acusaciones transmitidas por el periodismo, ejerció un cierto control de su imagen pública $^{72}$. Para ello, se mostró como un hombre serio, responsable y atado a los dictámenes de ley que por un lado, aseguraba la confidencialidad de los datos bancarios y por el otro, exigía las penalidades correspondientes que se derivaban de su propia investigación.

\section{El Informe Pillado y los escándalos del BPSF}

Aunque, Pillado no mencionó en su informe, de manera explícita, la palabra corrupción —-tal como sí ocurrió en la esfera periodística- empleó una diversidad de términos asociados a ella. Entre los más frecuentes se identifican: "falsedad de la ley", "fraude", "administración irregular", "ilegalidad", "operaciones ilícitas" y "falta de honradez" $"$.

A lo largo del escrito —al igual que en los discursos decimonónicosvisibilizamos dos acepciones implícitas del vocablo vinculadas a las esferas éticomoral y legal ${ }^{74}$. Respecto a la primera, observamos que Pillado - a diferencia de algunos de los editoriales aparecidos en las columnas de El Municipio y La Capitalcondenó, moralmente, no a políticos y empresarios, sino a los administradores de la entidad $^{75}$. Si bien, el comisionado denunció el incumplimiento de la normativa bancaria manifestó una fuerte crítica hacia los comportamientos de los directivos del BPSF. Pillado sostenía que el estado en el que se encontraba la entidad era consecuencia, no de falta de leyes, sino de la "impureza" de sus hombres. Según él, era necesario restituir en la administración a quienes personificaran ciertos valores morales. En consecuencia, se mejoraría el funcionamiento del BPSF y se

$<$ https://biblio1.rosario.gob.ar/cgi-bin/koha/opacsearch.pl?q=El+Municipio+1890\&branch group limit=>.

${ }_{71}^{70}$ Congreso de la Nación. Diario de sesiones de la Cámara de Diputados... Op. cit., pp. 622-623.

${ }^{71}$ El escrito estuvo dirigido al director del diario porteño La Prensa y fue reproducido en La Capital con el nombre de: La cuestión santafesina. Ecos de la prensa, Tapones esmerilados. La Capital. $1 / 9 / 1894$.

72 Este rasgo lo encontramos presente en otros escándalos de corrupción. DALMAU, Pol. La reputación del notable... Op. cit, p. 93.

${ }_{73}$ PILLADO, Ricardo. Intervención Nacional... Op. cit., pp. 46 y 53.

${ }^{74}$ GIORDANO, Verónica. Qué va cha ché... Op. cit., p. 79; La corrupción política... Op. cit., p. 263. PEÑA GUERRERO, María Antonia y BONAUDO, Marta. Presentación... Op. cit., p. 14.

${ }^{75}$ La Misión Pillado. La intervención oportuna... Op. cit.; Los Bancos y la política provincial. El Municipio [en línea] 10/9/1890. Disponible en <https://biblio1.rosario.gob.ar/cgi-bin/koha/opacsearch.pl?q=El+Municipio+1890\&branch group limit $=>$. 
recuperaría la ejemplaridad que había caracterizado a la firma a lo largo de los años ${ }^{76}$.

El comisionado —durante la investigación- enumeró dos de valores que debían imperar en las autoridades futuras del BPSF. Entre esos méritos destacó la honradez y el patriotismo. En una parte de su informe Pillado escribió: "[...] Yo creo señor Ministro que el único remedio ahora, es poner este establecimiento en liquidación entregándolo á manos puras y á caracteres levantados y patriotas [...]"77. Desde la perspectiva del funcionario, sólo se lograría una administración honrada, si el BPSF era dirigido por un conjunto de personas respetuosas de los mandatos de la ley ${ }^{78}$. Estos supuestos se cristalizaron -años después- en la elaboración de un proyecto presentado por el ejecutivo provincial para la reorganización de la firma ${ }^{79}$. Aunque, no solo fue el mal manejo del banco lo que inclinó a las autoridades a reestructurarlo, sino el impacto económico y financiero que la crisis ocasionó, ello no debe ser pasado por alto. Este aspecto del problema nos introduce en el debate sobre las consecuencias de las denuncias de corrupción. Así, en palabras de otros autores, Pillado persiguió una crítica, más bien, estratégica porque con su informe pretendió forjar cambios institucionales para la mejora de la administración de la entidad, tal como ocurrió luego ${ }^{80}$.

Asimismo, Pillado sostuvo que las nuevas autoridades debían manifestar valores patrióticos. La palabra "patriotismo" no era privativa del comisionado, sino que fue utilizada por diferentes actores políticos y sociales en el contexto de la crisis de 1890 y en las manifestaciones públicas en contra de la reunificación de la deuda externa argentina en $1901^{81}$. Inés Rojkind - retomando lo dicho por el legislador Manuel Pizarro en el Congreso Nacional- argumentó que el término "patria" había sido empleado para advertir que ella se encontraba en peligro como consecuencia de la debacle de $1890^{82}$. También, el presidente Pellegrini introdujo el vocablo en un discurso - pronunciado en 1891- ante las cámaras legislativas con motivo de la inauguración de las sesiones ordinarias del congreso. En este sentido, el mandatario nacional manifestó que esa época era de "profunda ansiedad para el patriotismo"

\footnotetext{
${ }^{76}$ PILLADO, Ricardo. Intervención Nacional... Op. cit., p. 30.

77 PILLADO, Ricardo. Intervención Nacional... Op. cit., p. 24.

78 PILLADO, Ricardo. Intervención Nacional... Op. cit., p. 30. Según las concepciones de la época, la palabra honradez estaba asociada al buen desempeño profesional y al respeto por los bienes públicos. GAYOL, Sandra. Honor y duelo en la Argentina moderna. Buenos Aires: Siglo Veintiuno Editores, 2008, p. 44.

${ }^{79}$ Ministerio de Hacienda. Reorganización del Banco Provincial... Op. cit.

${ }^{80}$ RUDERER, Sthephan y ROSENMÜLLER, Cristoph. Introducción. La nueva historia de la corrupción en América Latina. En: RUDERER, Sthephan y ROSENMÜLLER, Christoph. Introducción. La nueva historia de la corrupción en América Latina. En: ROSENMÜLLER, Christoph y RUDERER, Sthephan (eds.). "Dádivas, dones y dinero". Op. cit., pp. 13-14.

${ }^{81}$ ROJKIND, Inés. Prensa, manifestaciones y oposición política. La protesta contra la unificación de la deuda en julio de 1901. Estudios Sociales [en línea]. 2006, vol. 1, n. 31, p. 142. [Consulta: 12-72020]. Disponible

en <https://bibliotecavirtual.unl.edu.ar/publicaciones/index.php/EstudiosSociales/issue/view/253>; BONAUDO, Marta. 1889/1893... Op. cit., p. 110.

${ }^{82}$ ROJKIND, Inés. El triunfo moral... Op. cit., p. 186.

83 PELLEGRINI, Carlos. Congreso Nacional Cámara de Senadores. Sesión de apertura del Congreso Legislativo Federal en su período 1891 [en línea]. Buenos Aires: s/d, 9 de mayo de 1891. [Consulta 22-06-2020].

Disponible 
Tal como lo ha afirmado Gabriel Di Meglio —durante la segunda mitad del siglo XIX - la palabra "patria" remitía a una identidad superior asociada a la Argentina ${ }^{84}$. Al respecto, Pillado hizo referencia a la expresión "acción patriótica" para aludir al tipo de conducta que debían exteriorizar las autoridades bancarias en un momento en que había sucumbido la nación toda. Las acciones de los directivos del BPSF según él- permitirían que la entidad restableciera su crédito ${ }^{85}$. Por otra parte, Pillado consideró que su labor investigativa contribuiría a los objetivos planteados por el presidente Pellegrini, es decir, salvar al "país de la bancarrota y del descrédito primero" ${ }^{86}$.

Además, Pillado vinculó a la "corrupción" con el incumplimiento de la normativa bancaria por parte de los directivos del BPSF. Estas percepciones se encontraban presentes en la prensa diaria de la época ${ }^{87}$. Al igual, que en el periodismo -nacional y local- Pillado pretendía que su acción ayudara a combatir la impunidad de los hechos escandalosos ${ }^{88}$. Su misión tenía por fin que las conductas anómalas no fueran, ni encubiertas, ni silenciadas. La tarea emprendida por él serviría para "pedir el cumplimiento de la ley y las sanciones respectivas en los casos de infracción" 89 . En definitiva, como lo manifestó el comisionado, en otra parte del escrito, su trabajo tenía como horizonte salvaguardar "el bien de la comunidad" funcionario reconoció que los comportamientos irregulares de los directivos del BPSF habían dañado el bien común de la sociedad santafesina.

\section{El informe Pillado y sus consecuencias}

Pillado, ateniéndose al imperio de la ley, presentó ante la Justicia Federal una denuncia penal en contra de las autoridades bancarias. Tal como lo hemos indicado, el pedido no prosperó. Dos parecen haber sido las causas de ello. La primera, se correspondió con el mismo proceso investigativo. Uno de los denunciados, el interventor del BPSF, Desiderio Rosas, acusado de incumplir algunas de sus funciones, era también el fiscal titular de la causa. La demora en el nombramiento de una persona que sucediera a Rosas, dada la incompatibilidad de cargos, habrían retrasado el curso de los hechos. Una segunda, estuvo vinculada a las críticas de los miembros del poder ejecutivo y legislativo provincial que ponían en duda la legalidad del decreto presidencial que había establecido el inicio de la investigación ${ }^{91}$.

\footnotetext{
<https://www.hcdn.gob.ar/secparl/dgral info parlamentaria/dip/archivos/1891 Mensaje presidencial Pellegrini.pdf\#page=1\&zoom=auto,-101,842>.

84 DI MEGLIO, Gabriel. Patria. En: GOLDMAN, Noemí (ed.). Lenguaje y revolución. Conceptos políticos clave en el Ríos de la Plata 1780-1850. Buenos Aires: Prometeo Libros, 2008, p. 128.

${ }^{85}$ PILLADO, Ricardo. Intervención Nacional... Op. cit., p. 24.

${ }^{86}$ PELLEGRINI, Carlos. Congreso Nacional... Op. cit.

87 La Capital 29/8/1894. GARCILAZO, Romina. Los escándalos de corrupción... Op. cit., p. 220.

88 El diario La Nación también denunció la impunidad juarista. ALONSO, Paula. Jardines secretos, legitimaciones públicas. El Partido Autonomista Nacional y la política argentina de fines del siglo XIX. Buenos Aires: Edhasa, 2010, p. 327. Las ideas sobre las irregularidades en el BPSF se expresaron en los editoriales de El Municipio del 11/10/1890. GARCILAZO, Romina. Los escándalos de corrupción... Op. cit., p. 220.

89 PILLADO, Ricardo. Intervención Nacional... Op. cit., p. 40.

90 PILLADO, Ricardo. Intervención Nacional... Op. cit., p. 30.

${ }^{91}$ PILLADO, Ricardo. Intervención Nacional... Op. cit., p. 52.
} 
Entre las faltas comprobadas Pillado distinguió la adulteración de billetes y la inexistencia del encaje metálico en oro. Estas anomalías eran penadas por la Ley de Bancos Garantidos. Asimismo, ellas daban cuenta de otra infracción cometida por la administración del BPSF, la presentación de balances inexactos ante la Oficina Inspectora de Bancos Garantidos, órgano encargado de controlar a las instituciones financieras adheridas a la ley. Según la normativa los bancos tenían la responsabilidad de enviar a dicho órgano esa documentación con la conformidad de las autoridades ${ }^{92}$. Si bien, a lo largo del informe Pillado proporcionó diferentes estados contables de la entidad, que daban cuenta de la falsedad de los balances presentados, algunos datos facilitados el 4 de septiembre de 1890 al Ministro de Hacienda de la Nación, son reveladores. El funcionario constató que los valores encontrados en caja eran de $10.560,70 \$ \mathrm{~m} / \mathrm{n}$ y 23 . 080,05 en metálico. Esos montos resultaban muy inferiores a lo que necesitaba el BPSF para afrontar los $6.769 .115,01 \$ \mathrm{~m} / \mathrm{n}$ de los depósitos a su cargo, de los cuales eran exigibles $\$ 2.404$. $667,46 \$ \mathrm{~m} / \mathrm{n}$, judiciales $722.476 .021 \$ \mathrm{~m} / \mathrm{n}$ y en guarda $28.150,69 \$ \mathrm{~m} / \mathrm{n}$. Esta última suma permitió corroborar que la administración se había apropiado de los fondos que habían sido entregados al BPSF para su resguardo ${ }^{93}$.

Asimismo, la investigación puso al descubierto que las autoridades del BPSF incumplieron con la obligación de destruir los billetes de circulación vencida que debían haber sido entregados al Banco Nacional para ser reemplazados por una partida nueva al momento de la incorporación del BPSF a la Ley de Bancos Garantidos. Cuando se llevó a cabo la inspección ese dinero aún estaba en circulación y era contabilizado entre los fondos de la entidad para disimular ante la Oficina Inspectora de Bancos Nacionales la endeble situación de la entidad ${ }^{94}$.

Con respecto al encaje bancario, el funcionario comprobó que de los $2.900 .000 \$$ oro con los que la entidad debía contar solo había $23.080,05$ \$ oro. El resto había sido prestado, fundamentalmente, a destacadas figuras locales como Juan Canals, Carlos Casado del Alisal, Javier Munuce y al mismo director de la entidad ${ }^{95}$. Paralelamente, dichas personalidades habían convenido la devolución del préstamo en amplios términos de tiempo y pago en papel, condiciones que alteraban la normativa ${ }^{96}$.

Por otra parte, la investigación de Pillado reveló un acuerdo controversial, el establecido entre la firma y el propio gobierno de la provincia de Santa Fe. Aunque,

\footnotetext{
${ }_{92}^{2}$ PILLADO, Ricardo. Intervención Nacional... Op. cit., p. 27.

${ }^{93}$ PILLADO, Ricardo. Intervención Nacional... Op. cit., pp. 21-22; QUESADA, Sixto. Historia de los Bancos Modernos. Bancos de descuentos. La moneda y el crédito. Tomo 2. Buenos Aires: M. Biedma é Hijo Editores, 1901, p. 562.

${ }_{94}$ PILLADO, Ricardo. Intervención Nacional...Op. cit, pp. 23-24; QUESADA, Sixto. Historia de los Bancos Modernos...Op. cit., pp. 561-562.

${ }^{95}$ PILLADO, Ricardo. Intervención Nacional... Op. cit., pp. 21, $22,24$.

Exponemos aquí algunas referencias biográficas de los personajes mencionados, a excepción de Oldendorff, al que nos referiremos luego. Canals fue un comerciante catalán radicado en Rosario que extendió su área de acción al ámbito inmobiliario, bancario y de la construcción. Por su parte, Casado se distinguió en la esfera comercial, bancaria y ferroviaria, a la vez que, fue un activo colonizador rural en la provincia de Santa Fe. Finalmente, Munuce, de origen español, fue uno de los notarios más reconocidos de la ciudad de Rosario durante este período.

${ }^{96}$ PILLADO, Ricardo. Intervención Nacional... Op. cit., p. 57.
} 
la regulación bancaria permitía al BPSF otorgar créditos al poder provincial o a los gobiernos locales, ellos debían limitarse a las terceras partes de sus rentas anuales. El valor convenido, en esa oportunidad, excedía la reglamentación ${ }^{97}$.

Si bien, los actos cometidos en el BPSF eran ilegales algunos eran punibles, penalmente, y otros exigían acciones civiles. Los primeros involucraron a los directivos de la entidad, mientras que los segundos, a los deudores. Según el comisionado del gobierno las causas civiles eran importantes de visibilizar:

"[...] no para que se deduzcan acciones, sino como pruebas coadyuvantes de la mala administración que ha colocado al Banco fuera de los términos de la ley $[\ldots]^{398}$.

Las denuncias se dirigieron, fundamentalmente aunque no exclusivamente, a Germán Oldendorff, gerente del BPSF desde enero de 1887 hasta mayo de 1890, momento en que fue designado director hasta septiembre de ese mismo año ${ }^{99}$. Las acusaciones se sustentaron en el artículo 34 de la Ley de Bancos Garantidos que condenaba a la pena de, seis meses a diez años de prisión, a los directores y/o gerentes que suministraran informes o datos inexactos a la Oficina Inspectora. También, la denuncia se fundamentó en la Ley Provincial de 1876 que responsabilizaba a los gerentes de las firmas por las acciones que se realizasen, más allá, de lo establecido en los estatutos del BPSF. Según el resultado de la investigación, Oldendorff habría adulterado los billetes de la entidad con el sello de la intervención nacional ${ }^{100}$.

Otro de los acusados fue Rosas que, durante el periodo 1885-1889, ocupó el cargo de interventor nacional del BPSF. Según la normativa, Rosas debía verificar la emisión, el encaje bancario, la circulación de billetes y los balances mensuales. Sin embargo, durante la investigación se comprobó que no había cumplido debidamente sus funciones ${ }^{101}$.

Con respecto a los principales deudores, la pesquisa puso en evidencia la irregularidad de algunos acuerdos bancarios celebrados con el consentimiento de la administración. Entre las anomalías, más resonantes, se visualizó el pago a plazos de los préstamos efectuados en oro a los particulares, como así también, la inexistencia del registro de una cuenta en metálico adeuda por el gobierno provincial $^{102}$.

\footnotetext{
${ }^{97}$ PILLADO, Ricardo. Intervención Nacional... Op. cit., pp. 46-47.

${ }^{98}$ PILLADO, Ricardo. Intervención Nacional... Op. cit., p. 62.

${ }^{99}$ Los estatutos de 1886 establecían que el BPSF sería administrado por un director general y un gerente, ambos designados por el poder ejecutivo provincial. Los funcionarios estarían acompañados por una Comisión Consultiva de cuatro miembros, dos de los cuales serían nombrados por el gobierno de Santa Fe, y los otros dos, por los accionistas. Banco Provincial de Santa Fe. Estatutos del Banco Provincial de Santa Fe. Rosario: La Capital, 1886, p. 7.

${ }_{100}$ PILLADO, Ricardo. Intervención Nacional... Op. cit., p. 56.

101 PILLADO, Ricardo. Intervención Nacional... Op. cit., p. 61. El BPSF, luego de haber sido incorporado a la Ley de Bancos Garantidos, operó con un número de billetes que no contaron con el sello del Banco Nacional, tal como lo establecía la normativa, sino que fue la propia entidad la encargada de imprimir esa rúbrica.

${ }^{102}$ PILLADO, Ricardo. Intervención Nacional... Op. cit., p. 57.
} 
En el informe elaborado por el funcionario se hizo una distinción concluyente entre las responsabilidades que les correspondían a los particulares y a quienes habían formado parte de la administración del BPSF. Los últimos, a diferencia de los primeros, debían ser, cabalmente, penalizados. Estas ideas se contraponían a las manifestaciones públicas vertidas por diarios como El Municipio o periódicos como La Cabrionera. Ambas empresas editoriales, a través de su prosa, inculparon de igual modo a directivos y empresarios ${ }^{103}$. En parte, esta actitud estuvo en concordancia con la condena moral que la prensa local -al igual que el periodismo nacional- otorgó a los escándalos de corrupción ${ }^{104}$.

Si bien, Pillado mencionó el acuerdo oneroso entre la administración y el gobierno provincial no dio demasiados detalles al respecto, ni tampoco reprobó tal irregularidad. En cambio, este hecho suscitó malestar en el periodismo local y los sectores opositores ${ }^{105}$.

Aunque, el proceso investigativo no derivó en una condena efectiva hacia los culpables, generó un fuerte castigo público. Incluso, algunos miembros del Autonomismo, que no estuvieron directamente sospechados, se vieron en la necesidad de brindar declaraciones en los medios periodísticos y los debates políticos. Uno de ellos fue el diputado Llobet. El legislador, refiriéndose a la misión de Pillado, pese a sus críticas, reconoció la veracidad de uno de los puntos nodales de la denuncia: las irregularidades administrativas en el BPSF. En relación a esta temática, Llobet aseguró: "Yo no negaré, señor, que la administración del banco ha sido, en cierto modo, una administración defectuosa" ${ }^{106}$. El mismísimo ex gobernador Gálvez, y entonces senador nacional, tuvo apreciaciones similares al ser interpelado, personalmente, por los miembros de la oposición. Sin embargo, a diferencia de Llobet, el político se esforzó en quitarle cualquier tipo de responsabilidad al gobierno provincial:

"[...] El Banco tiene sus asambleas de accionistas que deliberan y disponen de su manejo [...] Yo, no estoy en condiciones, repito, de explicar hechos que resultaran de los libros y balances del Banco y que deben ser juzgados con arreglo á ellos, sin que su juzgamiento pueda alcanzar al gobierno que no lo administra [...]"107.

Más aún, Gálvez -en su discurso- se defendió de uno de los asuntos que lo involucraba de manera directa como la deuda contraída por el gobierno provincial durante su gestión-con el BPSF. Respecto a este tópico, el político sostuvo que la

\footnotetext{
${ }^{103}$ Sobre Juan Canals se dedicaron distintos editoriales, durante el mes de diciembre de 1889 , en el periódico local La Cabrionera. Respecto a la responsabilidad de los especuladores en el cuadro de desastre general, véase: Los escándalos bancarios. Los hechos actuales y las esperanzas. El Municipio [en línea] 11/10/1890. Disponible en <https://biblio1.rosario.gob.ar/cgi-bin/koha/opacsearch.pl?q=El+Municipio+1890\&branch group limit $=>$.

$104 \mathrm{HIRSCH}$, Leandro. La prensa independiente...Op. cit., p. 74; GARCILAZO, Romina. Los escándalos de corrupción... Op. cit, p. 225. Ese discurso moral también, operó en otros espacios sociales. ROJKIND, Inés. El triunfo moral... Op. cit.

${ }^{105}$ Réplica del Dr. Lejarza. Coimas y coimeros. Gálvez, Canals, etc. El Municipio [en línea]. 11/9/1894. Disponible en $<$ https://biblio1.rosario.gob.ar/cgi-bin/koha/opacsearch.pl?q=El+Municipio+1894\&branch group limit=>. ${ }^{106}$ Congreso de la Nación. Diario de sesiones de la Cámara de Diputados... Op. cit., p. 626.

${ }^{107}$ Congreso de la Nación. Diario de sesiones de la Cámara de Senadores... Op. cit., p. 301.
} 
suma de dinero adeudada correspondía no solo al gobierno provincial, sino a la receptoría de cuentas de Rosario y Santa $\mathrm{Fe}^{108}$.

Por otra parte, Llobet reconoció otra de las anomalías sobre la cual la investigación aportó evidencia: la discrecionalidad de la administración del BPSF en el otorgamiento de créditos. Sobre este tema, el legislador dijo:

“[...] El informe fue malicioso [...] Lo único que tenía de verdad era la parte que aseguraba que se había abusado del crédito en ciertas condiciones, todo lo demás estaba basado en informes falsos, en hechos que resultaban completamente infundados" ${ }^{\prime 109}$.

De igual modo, Canals, uno los principales deudores de la firma, debió explicar, públicamente, cómo había sido su vínculo con el BPSF. En una de sus declaraciones al diario La Capital, no negó el abultado crédito otorgado, sino que justificó el proceder del banco. En relación a esta cuestión, el empresario sostuvo:

"[...] Debo gratitud inmensa á ese establecimiento, que ha hecho excesivo honor á la honradez de mi firma. El tuvo fé en mí, como yo la tenía en la grande prosperidad de la república y al invertir en valores los caudales que puso a disposición, ni el Banco ni yo pudimos imaginarnos la inmensa depreciación que iba a venir con esto. Pero conste que no he hecho con el Banco operación alguna que no conste en sus libros [..." $]^{\prime 110}$.

Canals, al igual que Llobet, reconoció con la expresión "excesivo honor" que había recibido un trato preferencial en el BPSF. Asimismo, el legislador en el recinto parlamentario — con similares palabras_- manifestó esas ideas:

"El gran crimen que se cometió con el Banco de la Provincia, el crimen más punible de ese directorio y del señor Canals mismo, fué el abuso del crédito $[\ldots]^{\prime 111}$.

En cambio, Oldendorff procedió de un modo ambivalente ante las denuncias. El directivo -antes que Pillado presentase el informe ante la Justicia Federalrenunció a su cargo, aduciendo motivos personales ${ }^{112}$. Con posterioridad, y una vez que las irregularidades salieron a la luz, al igual que empresarios y políticos, Oldendorff desmintió, públicamente, las acusaciones ${ }^{113}$. Aunque también, el dirigente ensayó otros canales de negociación política, de carácter privado, con algunos de los referentes del Autonomismo local. Según el diario, El Municipio, Oldendorff, luego

\footnotetext{
108 Ibídem.

${ }^{109}$ Congreso de la Nación. Diario de sesiones de la Cámara de Diputados... Op. cit., p. 624.

${ }^{110}$ CANALS, JUAN. Otro más de la palestra. Una carta de Juan Canals. La Capital 4/9/1894.

${ }_{111}$ Congreso de la Nación. Diario de sesiones de la Cámara de Diputados... Op. cit., p. 623.

112 Renuncia del señor Oldendorff. El Municipio [en línea]. 19/9/1890. Disponible en $<$ https://biblio1.rosario.gob.ar/cgi-bin/koha/opacsearch.pl?q=El+Municipio+1890\&branch group limit $=>$.

${ }^{113}$ En una noticia, publicada en un matutino local, corrió el rumor que el ex gobernador Gálvez habría solicitado al funcionario del BPSF hacer declaraciones públicas sobre lo acontecido en dicha entidad. Gálvez y Oldendorff. El Municipio [en línea]. 10/9/1890. Disponible en $<$ https://biblio1.rosario.gob.ar/cgi-bin/koha/opacsearch.pl?q=El+Municipio+1890\&branch group limit=>.
} 
de publicado el informe, acudió al gobernador autonomista Juan Manuel Cafferata (1890-1893) con la intención de que: "[...] hiciese uso de su influencia personal hacia los inspectores [...] con el objeto de que no se siguiera el asunto ó al menos se atentaran en lo posible los cargos [... $]^{\prime 114}$.Si bien, no se tienen referencias precisas de la filiación política de Oldendorff este tipo de acciones nos hacen suponer que mantenía vínculos más bien cercanos con la dirigencia provincial. Sin embargo, esas tramas políticas parecen haberse tensionado como consecuencia del escándalo del BPSF. En la misma nota mencionada con anterioridad El Municipio informó que el gobernador había sido indiferente al pedido de ayuda del director de la entidad. Ante esta actitud el matutino dio a entender que Oldendorff habría advertido al gobernador que si el peso de la ley recaía sobre él los miembros del autonomismo que, habían disfrutado de los beneficios bancarios, lo acompañarían en tan dura proeza ${ }^{115}$.

Finalmente, Rosas, parece haber compartido con Oldendorff estas actitudes de defensa. Al igual que el director de la entidad, el ex interventor había apelado a la buena voluntad de uno de los máximos representantes del Autonomismo nacional, Julio A. Roca, con el objeto de buscar en él cierta protección ante las acusaciones que lo involucraban con el escándalo del BPSF $^{116}$. Además de estos vínculos políticos con el oficialismo, Rosas participó de algunas iniciativas económicas lideradas por empresarios ligados al círculo galvista, como Canals. Fue accionista y miembro -en calidad de suplente- del Banco Sindical firma dedicada a la compra y venta de inmuebles. Este último aspecto pone en evidencia la labilidad de la esfera política y económica que explican buena parte de la lógica con la que operó ciertos sectores ligados al autonomismo provincial y que tuvo en el BPSF uno de sus escenarios privilegiados ${ }^{117}$.

\section{Consideraciones finales}

A lo largo del presente artículo, hemos observado cómo - a inicios de la década de 1890- los escándalos de corrupción, en torno a las anomalías en el BPSF, se proyectaron en el escenario periodístico derivando, luego, en una investigación gubernamental que exigió la acción judicial. En este sentido, y en relación con las percepciones sociales y políticas en la Argentina a partir de 1890, observamos que la intolerancia sobre el hecho corrupto ya comenzaba a trastocar a los mismos poderes del Estado.

En su informe Pillado no solo comprobó con documentación fidedigna, proveniente de la institución, ciertos hechos catalogados públicamente como corruptos, sino que vinculó el término a las esferas legal -las autoridades habían transgredido las normas dañando el bien común de la sociedad santafesina- y moral -los actores involucrados actuaron faltando a los valores de patriotismo y honradez-

\footnotetext{
114 Actitud del señor Oldendorff. El Municipio [en línea] 16/10/1890. Disponible en $<$ https://biblio1.rosario.gob.ar/cgi-bin/koha/opacsearch.pl?q=El+Municipio+1890\&branch group limit=> ${ }^{115}$ Ibídem.

116 BONUADO, Marta. El partido de notables en el juego cruzado de <<influencias legítimas >> e <<intereses calculados>> (1853-1900). Ayer. Revista de Historia Contemporánea [en línea]. 2020, vol. 2, n. 118, p. 38. [Consulta: 20-07-2021]. Disponible en <https://revistaayer.com/anteriores/1408>.

${ }^{117}$ Sobre este tema, véase: GARCILAZO, Romina. Empresariado y poder político..., Op. cit.
} 
en consonancia con las ideas imperantes de la época. Contrariamente, a las concepciones de la prensa, el comisionado orientó sus denuncias, más enérgicas, en contra de los directivos de la entidad y no hacia los políticos y empresarios involucrados. Probablemente, ello se debió a la propia estructura legal que exceptuaba a los primeros de acciones punibles penalmente.

Sin embargo, el periodismo y el agente del gobierno manifestaron mayores coincidencias en lo que respecta a sus propias misiones. Ambos concluyeron que sus acciones - una desarrollada desde las columnas de los periódicos y la otra desde el Estado- contribuirían a combatir la impunidad de los hechos escandalosos en defensa del bien común. En distintos momentos, la prensa se filtró en el proceso investigativo convirtiéndose en una fuente de información, un canal de defensa, pero también, un obstáculo que podía dificultar la labor de Pillado. Su acción llevó incluso a que el denunciante, al igual que los denunciados, tuviera que "purificar" su propia imagen pública.

Asimismo, el caso demuestra que, al igual que lo sucedido en la Argentina y en otros países, la justicia no fue la vía más efectiva para condenar a los actores que habían transgredido las normas bancarias. Particularmente aquí, las demoras en el proceso judicial se originaron por la incompatibilidad de cargos de algunos de los personajes intervinientes y las críticas ensayadas por los políticos locales. Pese a ello, el informe generó una fuerte disrupción política y social. Tanto políticos, directores de bancos y empresarios debieron justificar y explicar, públicamente, sus propias acciones, ya que fueron interpelados por buena parte de la sociedad. Si bien, los miembros del Autonomismo local intentaron desprenderse de toda acusación que los vinculara a las irregularidades parece haber existido un cierto consenso entre denunciantes y denunciados, el reconocer las irregularidades administrativas. Incluso, esas interpelaciones no solo exigieron declaraciones públicas, sino que desencadenaron consecuencias más graves para algunos de ellos, como el tener que abandonar sus cargos en el organismo.

Pese a las impericias judiciales, luego del paso del comisionado por el BPSF, algunas cosas habían quedado en claro. Las anomalías en la entidad parecían estar comprobadas, las denuncias de corrupción podían llegar a la justicia y quienes eran blancos de ellas debían justificar públicamente sus acciones. La tarea de Pillado en Santa Fe duró poco tiempo, pero a la luz de sus efectos podemos advertir que tuvo un largo derrotero. Quizás y de manera premonitoria esa frase de La Capital, con la que iniciamos el escrito de algún modo, se había cumplido. Esa delicada misión había traído grandes descubrimientos y revelaciones.

\section{Bibliografía y fuentes}

ALEM, Leandro [et al.]. Manifiesto de la Junta Revolucionaria (1890). En: BOTANA, Natalio y GALLO, Ezequiel. De la República posible a la República verdadera (1880-1910). Buenos Aires: Ariel Historia, 1997, pp. 231-235.

ALONSO, Paula. Jardines secretos, legitimaciones públicas. El Partido Autonomista Nacional y la política argentina de fines del siglo XIX. Buenos Aires: Edhasa, 2010. 
Argentina. Ministerio de Hacienda. Bancos de Emisión y Hacienda Pública. Buenos Aires: La Tribuna Nacional, 1889.

BALESTRA, Juan. El noventa. Una evolución política argentina. Buenos Aires: Hyspamérica, 1986.

Banco Provincial de Santa Fe. Estatutos del Banco Provincial de Santa Fe. Rosario: La Capital, 1886.

Banco Provincial de Santa Fe. Leyes referentes al Banco Provincial de Santa Fe. Santa Fe: s/d, 1895.

BOIXAIDÓS, Cristina. El financiamiento de la expansión urbana a través de la documentación del Banco de la provincia de Córdoba 1880/1895. Revista de Economía y Estadística. 1986-1989, n. 27, pp. 1-32.

BONAUDO, Marta. De representantes y representados: Santa Fe finisecular (18831893). En: SABATO, Hilda (coord.). Ciudadanía política y formación de las naciones. Perspectivas históricas de América Latina. México: Fondo de Cultura Económica, 1999, pp. 270-294.

BONUADO, Marta. El partido de notables en el juego cruzado de <<influencias legítimas >> e <<intereses calculados>> (1853-1900). Ayer. Revista de Historia Contemporánea [en línea]. 2020, vol. 2, n. 118, pp. 17-47. [Consulta: 20-072021]. Disponible en $<$ https://revistaayer.com/anteriores/1408>.

BONAUDO, Marta. Repensando el partido/facción en la experiencia latinoamericana. Illes i Imperis. Estudios de Historia de las sociedades en el mundo colonial y post-colonial [en línea]. 2015, n. 17, pp. 15-42. [Consulta: 17-05-2020]. Disponible en <https://dialnet.unirioja.es/ejemplar/414735>.

BONAUDO, Marta. 1889/1893 ¿Un nuevo umbral de la percepción de la corrupción política? En: PEÑA GUERRERO, María Antonia y FERIA LORENZO, Diego (dirs.). Corrupción política y liberalismo en el largo siglo XIX. Granada: Comares Historia, 2020, pp. 101-117.

BONAUDO, Marta y SONZOGNI, Elida. Empresarios y poder político en el espacio santafesino (1860-1890). Carlos Casado y su estrategia de acumulación. Historia y Grafía. 1998, n. 11, pp. 39-64.

Congreso de la Nación. Diario de sesiones de la Cámara de Diputados. Buenos Aires: Imprenta del "Congreso", 1894.

Congreso de la Nación. Diario de sesiones de la Cámara de Senadores: Buenos Aires: Establecimiento Topográfico "El Comercio", 1894.

DALLA-CORTE CABALLERO, Gabriela. Lealtades firmes. Redes de sociabilidad y empresas: <La Carlos Casado S.A> entre la Argentina y el Chaco Paraguayo (1860-1940). Madrid: Consejo de Investigaciones Científicas, 2009. 
DALMAU, Pol. La reputación del notable. Escándalos y capital simbólico en la España Liberal. Historia y Política: ideas, procesos y movimientos sociales [en línea]. 2018, n. 39, pp. 79-107. [Consulta: 27-04-2020]. Disponible en $<$ https://dialnet.unirioja.es/ejemplar/485413>.

DALMAU, Pol y BURDIEL, Isabel. Presentación. Imagen pública del poder. Escándalos y causas célebres en Europa (siglos XIX-XX). Historia y Política: ideas, procesos y movimientos sociales [en línea]. 2018, n. 39, pp.17-22. [Consulta: 27-04-2020]. Disponible en <https://dialnet.unirioja.es/ejemplar/485413>.

DE MARCO, Miguel Ángel. El contralor del Estado en la transformación argentina. Tierras, ferrocarriles y obras públicas en Santa Fe. Rosario: Universidad Católica Argentina, 2002.

DI MEGLIO, Gabriel. Patria. En: GOLDMAN, Noemí (ed.). Lenguaje y revolución. Conceptos políticos clave en el Ríos de la Plata 1780-1850. Buenos Aires: Prometeo Libros, 2008, pp. 115-130.

ENGELS, Jens Ivo. Corruption and Anticorruption in the Era of Modernity and Beyond. En: KROEZE, Ronald [et al.] (eds.). Anticorruption in History. From Antiquity to the Modern Era. Oxford: Oxford University Press, 2018, pp. 167-180.

ENGELS, Jens Ivo. La "modernidad" de la corrupción. En: PEÑA GUERRERO, María Antonia y BONAUDO, Marta (dirs.). Historia cultural de la corrupción política. Prácticas, escenarios y representaciones contemporáneas. Rosario: Prohistoria Ediciones, 2019, pp. 19-33.

ENGELS, Jens Ivo. La nueva historia de la corrupción. Algunas reflexiones sobre la historiografía de la corrupción política en los siglos XIX y XX. Ayer. Revista de Historia Contemporánea [en línea]. 2019, n. 115, pp. 28-29. [Consulta: 27-092020]. Disponible en <http://revistaayer.com/anteriores/1362>.

FERREYRA, Silvana. Usos políticos de la corrupción en el enfrentamiento peronismo-antiperonismo. Una lectura desde las comisiones investigadoras en 1955 en Argentina [en línea]. Barcelona: Institut de Ciencies Politiques i Socials, Adscrit a la Universitat Autónoma de Barcelona, 2019. [Consulta: 23-04-2020]. Disponible en <https://www.icps.cat/archivos/Workingpapers/wp356.pdf >.

GALLO, Ezequiel. El gobierno de Santa Fe vs. El Banco de Londres y Río de la Plata (1876). Revista Latinoamericana de Sociología. 1971, vol. 2/3, n. 7, pp. 147-174.

GARCILAZO, Romina. Imágenes, discursos y escándalos de corrupción. El Banco Provincial de Santa Fe 1889-1894. Anuario del Instituto de Historia Argentina [en línea]. 2019, vol. 19, n. 2, pp. 1-17. [Consulta: 15-09-2020]. Disponible en $<$ https://www.anuarioiha.fahce.unlp.edu.ar/search/authors/view?firstName=Romi na\&middleName $=$ \&lastName $=$ Garcilazo\&affiliation $=$ UNRISHiR\%2FCONICET\&country=AR >. 
GARCILAZO, Romina. Empresariado y poder político. El Partido del Pueblo en Santa $\mathrm{Fe}$ (Argentina) hacia fines del siglo XIX. Ayer. Revista de Historia Contemporánea [en línea] 2020, n. 118, pp. 49-75. [Consulta: 20-07-2021]. Disponible en $<$ https://revistaayer.com/anteriores/1408>.

GARCILAZO, Romina. Los escándalos de corrupción retratados por la prensa. EI caso del Banco Provincial de Santa Fe (Argentina) segunda mitad del siglo XIX. Anuario Colombiano de Historia Social y de la Cultura [en línea]. 2019, vol. 1, n. 46, pp. 209-230. [Consulta 20-09-2020]. Disponible en $<$ https://revistas.unal.edu.co/index.php/achsc/issue/view/5066> $>$.

GARCILAZO, Romina. Voces disidentes en el Parlamento Nacional. Escándalo, corrupción y denuncias cruzadas. Santa Fe (Argentina), últimas décadas del siglo XIX. En: PEÑA GUERRERO, María Antonia y BONAUDO, Marta (dirs.). Historia cultural de la corrupción política. Prácticas, escenarios y representaciones contemporáneas. Rosario: Prohistoria Ediciones, 2019, pp. 89101.

GAYOL, Sandra. Honor y duelo en la Argentina moderna. Buenos Aires: Siglo Veintiuno Editores, 2008.

GERCHUNOFF, Pablo; ROCCHI, Fernando y ROSSI, Gastón. Desorden y progreso. Las crisis económicas argentinas 1870-1905. Buenos Aires: Edhasa, 2008.

GIORDANO, Verónica. La corrupción política en Argentina, 1886-1890. Una mirada desde The Times de Londres. Sociohistórica [en línea]. 2000, n. 7, pp. 251-268. [Consulta: 27-05-2020]. Disponible en $<$ http://www.memoria.fahce.unlp.edu.ar/library?a=d\&c=arti\&d=Jpr2828>.

GIORDANO, Verónica. Qué va cha ché. Corrupción y poder político en la Argentina 1890 cien años después. Buenos Aires: Universidad de Buenos Aires, 2003.

HIRSCH, Leandro. "Prensa independiente" y crítica moral al juarismo (1889-1890). Estudios Sociales [en línea]. 2013, n. 44, pp. 73-100. [Consulta: 7-06-2020]. Disponible en $<$ https://dialnet.unirioja.es/servlet/articulo?codigo $=7624329>$.

LOTERSZTAIN, Israel. La corrupción política como causa de la crisis bancaria de 1890. Revista de Instituciones, Ideas y Mercados [en línea]. 2016, n. 64-65, pp. 143-165. [Consulta: 07-07-2020]. Disponible en <http://www.eseade.edu.ar/wpcontent/uploads/2017/08/6 lotersztain riim64 65.pdf>.

LOTERSZTAIN, Israel. Los Bancos se roban con firmas: corrupción y crisis en 1890. Buenos Aires: Turmalina, 2010.

MARICHAL, Carlos. Historia de la deuda externa en América Latina. México: Alianza Editorial Mexicana, 1988.

Ministerio de Hacienda. Reorganización del Banco Provincial de Santa Fe: mensaje presentado por el Poder Ejecutivo de la provincia a las Honorables Cámaras 
legislativas por Santa Fe. Santa Fe: Topografía La Tribuna Popular, 1894.

Ministerio de Hacienda, Justicia y Obras Públicas. Don Presidente del Banco Provincial del Rosario, solicita autorización para deducir terciaria de dominio excluyente del edificio que ocupa decretado por la Corte Suprema. Santa Fe: s/d, 1898.

Ministerio de Hacienda, Justicia y Obras Públicas. Banco Provincial (Rosario) arreglo de deuda de D, Juan Canals. Rosario: s/d, 1899.

MONIER, Frédéric. La corruption injustificable: debats publics, practiques de pouvoir, cultures politiques (XIXe-XXe siècles). Seminaire de philosophie du droit, Institut des hautes études sur la justice. París, 2014.

MONIER, Frédéric. ¿Un "régimen honesto"? Soberanía y virtud en la República Francesa (1870-1940). Ayer. Revista de Historia Contemporánea [en línea]. 2019, n. 115, pp. 51-75. [Consulta: 29-09-2020]. Disponible en $<$ http://revistaayer.com/anteriores/1362>.

NEWLAND, Carlos. Clase política y sector bancario en la Argentina de entreguerras: el caso del Banco Español y del Río de la Plata. América Latina en la Historia Económica [en línea]. 2020, vol. 2, n. 27, pp. 1-15. [Consulta 20-8-2020]. Disponible en <http://alhe.mora.edu.mx/index.php/ALHE/article/view/e1028>.

PELLEGRINI, Carlos. Congreso Nacional Cámara de Senadores. Sesión de apertura del Congreso Legislativo Federal en su período 1891 [en línea]. Buenos Aires: $\mathrm{s} / \mathrm{d}, \quad 1891 . \quad[C o n s u l t a$ 22-06-2020]. Disponible en $<$ https://www.hcdn.gob.ar/secparl/dgral info parlamentaria/dip/archivos/1891 M ensaje presidencial Pellegrini.pdf\#page=1\&zoom=auto,-101,842>.

PEÑA GUERRERO, María Antonia y BONAUDO, Marta (dirs.). Historia cultural de la corrupción política. Prácticas, escenarios y representaciones contemporáneas. Rosario: Prohistoria Ediciones, 2019a.

PEÑA GUERRERO, María Antonia y BONAUDO, Marta. Presentación. En: PEÑA GUERRERO, María Antonia y BONAUDO, Marta (dirs.). Historia cultural de la corrupción política. Prácticas, escenarios y representaciones contemporáneas. Rosario: Prohistoria Ediciones, 2019b, pp. 9-18.

PEREYRA, Sebastián. Política y transparencia. La corrupción como problema público. Buenos Aires: Siglo Veintiuno, 2013.

PERSELLO, Ana Virginia. Historia del Radicalismo. Buenos Aires: Edhasa, 2007.

PILLADO, Ricardo. Anuario Pillado de la deuda pública y sociedades anónimas establecidas en la República Argentina para 1899. Buenos Aires: La Nación, 1899.

PILLADO, Ricardo. Comentarios sobre los tratados de comercio argentinos. Buenos 
Aires: Talleres Gráficos del Ministerio de Agricultura, 1915.

PILLADO, Ricardo. Intervención Nacional del Banco Provincial de Santa Fé: documentos oficiales, 1890. Buenos Aires: s/d, 1891.

PILLADO, Ricardo. Política comercial argentina contribución a su estudio. Buenos Aires: Talleres de publicaciones de la Oficina meteorológica argentina, 1906.

POMER, León. La corrupción, una cultura argentina. Buenos Aires: Leviatán, 2004.

QUESADA, Sixto. Historia de los Bancos Modernos. Bancos de descuentos. La moneda y el crédito. Tomo 2. Buenos Aires: M. Biedma é Hijo Editores, 1901.

RIQUER, Borja. Cambó en la Argentina. Negocios y corrupción política. Buenos Aires: Edhasa, 2016.

RIQUER, Borja [et al.] (dirs.). La corrupción política en la España Contemporánea. Un enfoque interdisciplinar. Madrid: Marcial Pons, 2018.

ROCCHI, Fernando. El péndulo de la riqueza: la economía argentina 1880-1916. En: LOBATO, Mirta Zaida (dir.). El progreso, la modernización y sus límites (18801916). Buenos Aires: Sudamericana, 2000, pp. 15-69.

ROCCHI, Fernando. Dossier. La crisis de 1890: política, sociedad y literatura. Introducción. Entrepasados. Revista de Historia [en línea]. 2003, n. 24/25, pp. 19-27. [Consulta: 15-08-2020]. Disponible en $<$ https://ahira.com.ar/ejemplares/entrepasados-no-24-25/>.

ROJKIND, Inés. El triunfo moral del pueblo. Denuncias de corrupción y movilización política en Buenos Aires, a fines del siglo XIX. En: ROSENMÜLLER, Christoph y RUDERER, Sthephan (eds.). "Dádivas, dones y dinero". Aportes a una nueva historia de la corrupción en América Latina desde el Imperio español hasta la modernidad. Madrid: Iberoamericana Vervuert, 2016, pp.169-187.

ROJKIND, Inés. "La revolución está vencida, pero el gobierno está muerto". Crisis política, discursos periodísticos y demostraciones callejeras en Buenos Aires, 1890. Anuario de Estudios Americanos [en línea]. 2012, vol. 2, n. 69, pp. 507532. [Consulta: 15-7-2020]. Disponible en $<$ https://estudiosamericanos.revistas.csic.es/index.php/estudiosamericanos/articl e/view/578>.

ROJKIND, Inés. Prensa, manifestaciones y oposición política. La protesta contra la unificación de la deuda en julio de 1901. Estudios Sociales [en línea]. 2006, vol. 1 , n. 31, pp. 137-162. [Consulta: 12-7-2020]. Disponible en $<$ https://bibliotecavirtual.unl.edu.ar/publicaciones/index.php/EstudiosSociales/iss ue/view/253>.

ROMERO, Ana Leonor. El "escándalo Magnasco". Denuncia pública y controversia sobre el papel del Congreso en la Argentina del 1900. Jahrbuch für Geschichte 
Lateinamerikas /Anuario de Historia de América Latina [en línea]. 2019, n. 56, pp. 232-254. [Consulta: 15-7-2020]. Disponible en <https://journals.sub.unihamburg.de/hup1/jbla/article/view/147>.

RUDERER, Sthephan. Corrupción y violencia. Una relación ambivalente en Argentina y Uruguay en el siglo XIX. En: ROSENMÜLLER, Christoph y RUDERER, Sthephan (eds.). "Dádivas, dones y dinero". Aportes a una nueva historia de la corrupción en América Latina desde el Imperio español hasta la modernidad. Madrid: Iberoamericana Vervuert, 2016, pp. 147-168.

RUDERER, Sthephan y ROSENMÜLLER, Christoph. Introducción. La nueva historia de la corrupción en América Latina. En: ROSENMÜLLER, Christoph y RUDERER, Sthephan (eds.). "Dádivas, dones y dinero". Aportes a una nueva historia de la corrupción en América Latina desde el Imperio español hasta la modernidad. Madrid: Iberoamericana Vervuert, 2016, pp. 7-25.

TERRY, José. La crisis 1885-1892: sistema bancario. Buenos Aires: Imprenta Biegma, 1893.

THOMPSON, John. El escándalo político: poder y visibilidad en la era de los medios. Barcelona: Paidós Ibérica, 2001.

VITELLI, Guillermo. La corrupción como producto de los procesos históricos y de las lógicas de las estructuras político-económicas. En: Congreso Latinoamericano de Historia Económica. México: Centro Cultural Universitario Tlatelolco, 2010.

\section{Hemerografía}

La Capital, 1890; 1894.

El Municipio, 1890; 1894. 